\title{
ДОСЛІДЖЕННЯ СТАТИСТИЧНИХ ХАРАКТЕРИСТИК МОДИФІКОВАНОГО АЛГОРИТМУ ВВS ІЗ ЗАЛЕЖНІСТЮ ВІД ПОТОЧНОГО ТА ПОПЕРЕДНЬОГО ЗНАЧЕННЯ ПОСЛІДОВНОСТІ
}

\begin{abstract}
У системах захисту інформації широкого застосування набув генератор Блюма-Блюма-Шуба (BBS), який базується на використанні односторонньої функції факторизації, та належить до криптостійких. У роботі досліджено характеристики запропонованого автором модифікованого алгоритму BBS із залежністю від поточного та попереднього значення послідовності, зокрема, період повторення та статистичні характеристики вихідної послідовності залежно від параметрів генератора. Дослідження проведено з використанням тестів NIST і порівняно із класичним алгоритмом BBS. 3'ясовано, що період повторення класичного алгоритму BBS для малих значень ключа, від 5 до 10 бітів, становить не більше ніж 20 \% від його значення. Ця тенденція зберігається на ключах більшого розміру, від 15 до 21 бітів, де період повторення для вибраних початкових установок не перевищує 5,56 \%. Період повторення модифікованого алгоритму BBS для ключів від 5 до 10 бітів у середньому становить 200 \% від значення ключа. Така поведінка зберігається для вибіркових початкових установок для ключів від 15 до 21 бітів, період повторення яких в середньому становить $351 \%$. Дослідження статистичних характеристик пакетом статистичних тестів NIST проведено на згенерованих послідовностях із $10^{9}$ бітів для ключів завдовжки від 29 до 31 бітів. Встановлено, що статистичні портрети для класичного алгоритму $є$ не задовільними, зокрема, статистичні портрети для 31-бітного ключа мають до 5 незадовільних результатів із 188 тестів. Статистичні портрети для модифікованого алгоритму BBS є задовільними для ключів від 30 до 31 бітів, але не є задовільними для 29-бітного ключа - мають по одному незадовільному результату. Отже, модифікований алгоритм BBS має кращі значення періоду повторення та статистичні портрети порівняно із класичним алгоритмом, що дає змогу використовувати ключі меншої довжини при генеруванні послідовності, які вимагають менше ресурсів системи, оскільки операція піднесення до квадрату за модулем більш ресурсозатратна, ніж операція додавання. Подальші дослідження будуть зосереджені на апаратну реалізацію модифікованого алгоритму BBS та порівняння використаних ресурсів системи із реалізацією класичного алгоритму BBS.
\end{abstract}

Ключові слова: псевдовипадкова послідовність; генератори псевдовипадкових послідовностей; одностороння функція; генератор Блюма-Блюма-Шуба.

Вступ. У системах захисту інформації широкого застосування набув алгоритм BBS генератора (за прізвищами авторів Блюм (L. Blum), Блюм (M. Blum), Шуб (M. Shub)), запропонований авторами в 1986 p. [1, 2, 3, $5,6,8,9]$. Принцип роботи генераторів BBS базується на використанні односторонньої функції факторизації. Вони належать до криптостійких $[4,7,13]$ і спрямовані насамперед на програмну реалізацію. Враховуючи попереднє твердження, кожна ітерація алгоритму вимагає значних ресурсів системи. Для покращення статистичних характеристик класичного алгоритму BBS у роботі [12] запропоновано модифікації числа-модуль рекурентного рівняння, які попри кращі статистичні характеристики, вимагають більше ресурсів системи. На противагу попереднім, у роботі [10] запропоновано методи зі зміни залежності між попереднім та наступним членами послідовності, які вимагають відносно менше ресурсів системи. У роботі [10] частково розкрито вплив модифікацій на період повторення послідовності, але не розкрито питання їх статистичних характеристик, що підтверджує актуальність цієї роботи.
Для зменшення необхідних ресурсів запропоновано модифікації, наведені в роботах $[10,12]$, які мають на меті зменшити необхідний розмір ключа завдяки покращенню характеристик класичного алгоритму.

Об'єктом дослідження є генератори псевдовипадкових послідовностей на базі класичного та модифікованого алгоритмів BBS.

Предметом дослідження є методи і засоби, які дають змогу визначити статистичні характеристики псевдовипадкових послідовностей чисел, отриманих класичним і модифікованим алгоритмами BBS, а саме: період повторення послідовності та статистичні портрети на базі пакету статистичних тестів NIST.

Метою роботи є дослідження модифікованого алгоритму BBS генератора із залежністю від поточного та попереднього значень послідовності, зокрема, дослідження періодів повторення його вихідної послідовності чисел і дослідження статистичних характеристик 3 використанням тестів NIST.

Завдання дослідження охоплює аналіз періоду повторення та статистичних портретів для псевдовипадко-

\section{Інформація про автора:}

Малогловець Андрій Сергійович, аспірант, кафедра безпеки інформаційних технологій. Email: maloglovets@gmail.com; https://orcid.org/0000-0002-0490-7174

Цитування за ДстУ: Малогловець А. С. Дослідження статистичних характеристик модифікованого алгоритму BBS із залежністю від поточного та попереднього значення послідовності. Науковий вісник НлТУ України. 2020, т. 30, № 2. С. 122-128.

Citation APA: Malohlovets, A. S. (2020). Research of statistical characteristics for improved BBS algorithm with dependency on the current and previous values of the sequence. Scientific Bulletin of UNFU, 30(2), 122-128. https://doi.org/10.36930/40300222 
вих послідовностей, які були згенеровані за допомогою класичного та модифікованого алгоритмів BBS, та їх порівняння.

Наукова новизна результатів дослідження полягає у розроблені покращеного алгоритму BBS на базі модифікацій залежності наступного значення послідовності від іiі поточного та попереднього значень.

Практична значущість результатів дослідження полягає в отримані залежності періодів повторення від ключів для класичного та модифікованого алгоритмів BBS, а також побудові статистичних портретів згенерованих псевдовипадкових послідовностей чисел.

Матеріал і методи дослідження. Основою визначення періоду повторення послідовності $є$ знаходження довжини послідовності, у якій всі члени є унікальними. Це твердження є справедливим для класичного алгоритму BBS, оскільки кожна ітерація має тільки один змінний вхідний параметр - поточне значення послідовності. Оскільки модифікований алгоритм BBS має додатковий вхідний параметр, попереднє значення послідовності, то період повторення послідовності є ï довжина, у якій пари попереднього та поточного значень послідовності є унікальними.

Аналіз статистичних характеристик та побудова статистичних портретів класичного алгоритму BBS та його модифікації проведено на згенерованих послідовностях завдовжки $10^{9}$ бітів із виведенням найменш значущого біту під час кожної ітерації алгоритму за допомогою пакету із 15 статистичних тестів NIST 2.1.2, який розроблений Лабораторією інформаційних технологій, що є головною дослідницькою організацією Національного інституту стандартів і технологій США (NIST) [11]. Ïх метою $є$ визначення міри випадковості двійкових послідовностей, сформованих генераторами псевдовипадкових чисел. Ці тести засновані на різних статистичних властивостях, притаманних лише випадковим послідовностям чисел.

Аналіз літературних джерел. У роботах $[1,6,8]$ подано різні сфери застосування алгоритму BBS, основною перевагою якого $є$ криптостійкість, яка вимагає відповідних ресурсів системи. Алгоритм має значно меншу швидкодію, ніж не криптостійкі методи, хоча і вимагає менше ресурсів, ніж алгоритм RSA. Для вирішення проблеми із кількістю необхідних ресурсів та швидкодією розроблено кілька модифікацій алгоритмів роботи BBS генераторів [5, 10, 12], кожна 3 яких спрямована на покращення певних їх характеристик, основними $з$ яких $є$ : криптостійкість, статистичні характеристики (враховуючи період повторення вихідної послідовності), швидкодія, об'єм ключової інформації (довжина ключа). Узагальнюючи можливі підходи, можна виділити такі групи, враховуючи розташування змін:

1. Модифікації числа-модуль рекурентного рівняння, які були продемонстровані та досліджені у роботі [12]. В основі модифікацій лежить додаткова операція множення ключа на просте число. Згенеровані псевдовипадкові послідовності продемонстрували кращі статистичні портрети, але необхідні ресурси для обчислення одної ітерації прямо пропорційні до довжини ключа, тобто цей підхід має значно меншу швидкодію порівняно із класичним алгоритмом, залежно від розміру третього простого числа, враховуючи рекомендації до ключів у роботах $[2,3,5]$, а саме, рекомендовано, щоб всі числа, які входять до значення ключа, мали майже однакову довжину, а отже, дані модифікації передбачають збіль- шення необхідних ресурсів системи в 1,5 раза. Також, особливу увага звертають на можливість підвищення швидкодії шляхом формування на кожному такті не одного, а кількох бітів вихідної послідовності. Кількість вихідних бітів у цілях безпеки, які можуть бути використані, напряму залежить від довжини ключа.

2. Модифікації залежності між попереднім та наступним членами послідовності, які розроблено у роботі [10]. Було наведено значне покращення періоду повторення послідовності для малих значень ключів, при цьому система вимагає незначного збільшення ресурсів, яке має лінійний характер обчислювальної складності, порівняно із складною операцією піднесення до квадрата за модулем, яка має квадратичний характер обчислювальної складності.

Класичний алгоритм BBS. Робота класичного алгоритму BBS базується на такій моделі:

$$
\mathrm{x}_{\mathrm{n}+1}=x_{n}{ }^{2} \bmod M
$$

де: $\mathrm{x}_{\mathrm{n}}-$ поточне значення послідовності, $x_{n+1}$ - наступне значення послідовності, $M$ - ключ, який є результатом множення:

$$
\mathrm{M}=\mathrm{p} \cdot \mathrm{q} \text {. }
$$

де $p$ i $q$ - числа Блюма: непарні прості числа, для яких виконуються такі умови:

$$
p \equiv 3(\bmod 4), q \equiv 3(\bmod 4) .
$$

Період повторення послідовності є більшим для тих ключів $M$, для яких найбільший спільний дільник функцій Ейлера від $p$ та $q$ має менше значення $[3,7]$ :

$$
\text { НСД }(\phi(\mathrm{p}-1), \phi(\mathrm{q}-1)) \text {. }
$$

Оскільки значення ключа $M \epsilon$ незмінним для наступних ітерацій, то формула (1) залежить тільки від одного вхідного параметра:

$$
x_{n+1}=f\left(x_{n}\right) .
$$

Враховуючи можливі вхідні значення та операцію взяття числа за модулем, значення періоду повторення вихідної послідовності класичного алгоритму лежить у такому діапазоні:

$$
P \in[1, M-1) .
$$

Модифікований алгоритм BBS. Одним із способів проведення модифікацій класичного алгоритму $є$ видозміна залежності між поточним і наступним членами послідовності, зокрема на базі узагальненої моделі модифікації, яка додатково використовує два параметри $a$ i $b$, та має такий вигляд:

$$
x_{n+1}=f\left(x_{n}, a, b\right) .
$$

Одним із можливих варіантів реалізації узагальненої моделі (9) є такий модифікований алгоритм:

$$
x_{n+1}=\left(x_{n}{ }^{2}+a+b\right) \bmod M .
$$

$\mathrm{У}$ цій роботі розглядаємо варіант алгоритму (10) за умови:

$$
a_{2}=x_{n}+x_{n-1} \text { i } b=0,
$$

де $x_{n-1}-$ попереднє значення ітераційного циклу.

Отже, модифікований алгоритм BBS описується таким рівнянням:

$$
x_{n+1}=\left(x_{n}^{2}+x_{n}+x_{n-1}\right) \bmod M .
$$

Дослідження та порівняльний аналіз періодів повторення класичного і модифікованого алгоритмів BBS генераторів. Дослідження періодів повторення було здійснено на шести вибраних ключах $M$ із найменшим значенням НСД, відповідно до формули (4), бітова довжина яких становить від 5 до 10 , які задовольняють умову (3) (табл. 1). 
Табл. 1. Ключі $M$ для генератора BBS

\begin{tabular}{|c|c|c|c|c|c|}
\hline \multirow{2}{*}{$\begin{array}{c}№ \\
\text { П/ா } \\
\end{array}$} & \multicolumn{2}{|c|}{ Число Блюма } & \multirow{2}{*}{$\begin{array}{c}\text { Довжина } \\
\text { ключа } M \text {, біт }\end{array}$} & \multirow{2}{*}{$\begin{array}{l}\text { Значення } \\
\text { ключа } M\end{array}$} & \multirow{2}{*}{$\begin{array}{c}\text { Значення } \\
\text { НСД ключа } M\end{array}$} \\
\hline & $p$ & $q$ & & & \\
\hline 1 & 3 & 7 & 5 & 21 & 1 \\
\hline 2 & 3 & 11 & 6 & 33 & 1 \\
\hline 3 & 3 & 23 & 7 & 69 & 1 \\
\hline 4 & 3 & 43 & 8 & 129 & 1 \\
\hline 5 & 3 & 103 & 9 & 309 & 1 \\
\hline 6 & 3 & 179 & 10 & 537 & 1 \\
\hline
\end{tabular}

Для визначення періоду здійснювали перебір усіх можливих початкових значень $x_{i}-x_{0}$ у діапазоні:

$$
x_{0} \in[2, M-1] .
$$

Оскільки модифікація алгоритму BBS залежить від двох вхідних параметрів, то для визначення періоду повторення модифікованого алгоритму BBS (12) враховували як поточні, так і попередні значення згенерованої послідовності.

Для зручності порівняння результатів, подамо значення періоду повторення відносно значення ключа:

$$
P\left(x_{0}\right), \%=P\left(x_{0}\right) / M \text {. }
$$
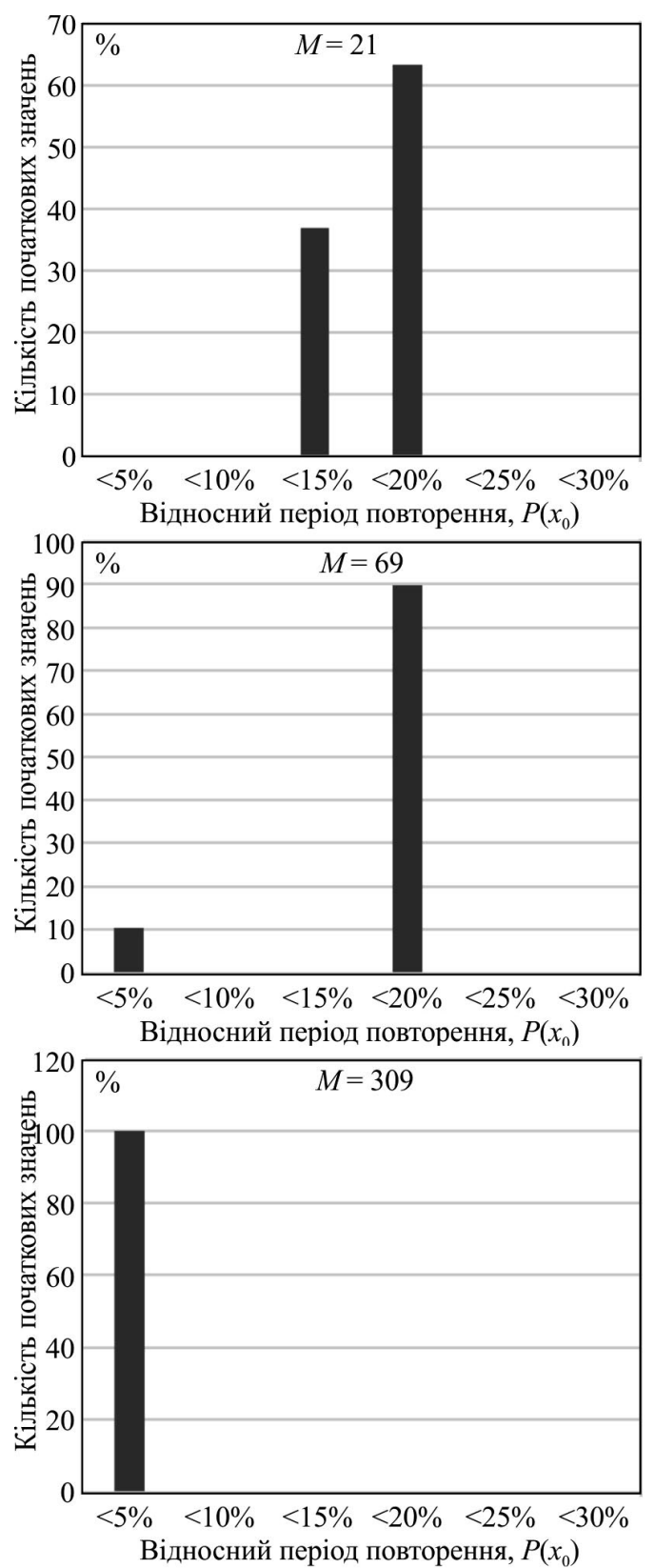

Рис. 1. Значення відносного періоду повторення від початкових значень для класичного алгоритму BBS
Залежності відносного періоду повторення від початкових значень $x_{0}$ для класичного алгоритму BBS наведено на рис. 1, а для модифікованого - на рис. 2. Результати, подані на рис. 1 , демонструють той факт, що період повторення класичного алгоритму BBS становить не більше ніж $20 \%$ від значення ключа $M$. Результати для модифікованого алгоритму BBS, зображені на рис. 2, відображають значне збільшення періоду повторення послідовностей. Усереднюючи отримані результати, можна зробити висновок, що період повторення модифіковано алгоритму досягає $200 \%$ від значення ключа, що є у 10 разів більше, ніж у класичного алгоритму.

\begin{tabular}{|c|c|c|c|c|c|}
\hline \multirow{2}{*}{$\begin{array}{l}\text { № } \\
\text { П/П }\end{array}$} & \multicolumn{2}{|c|}{ Число Блюма } & \multirow{2}{*}{$\begin{array}{c}\text { Довжина клю- } \\
\text { ча } M, \text { біт }\end{array}$} & \multirow{2}{*}{$\begin{array}{l}\text { Значення } \\
\text { ключа } M\end{array}$} & \multirow{2}{*}{$\begin{array}{c}\text { Значення } \\
\text { НСД }\end{array}$} \\
\hline & $p$ & $q$ & & & \\
\hline 1 & 3 & 5471 & 15 & 16413 & 1 \\
\hline 2 & 3 & 10939 & 16 & 32817 & 1 \\
\hline 3 & 3 & 21851 & 17 & 65553 & 1 \\
\hline 4 & 3 & 43691 & 18 & 131073 & 1 \\
\hline 5 & 3 & 87383 & 19 & 262149 & 1 \\
\hline 6 & 3 & 174763 & 20 & 524289 & 1 \\
\hline 7 & 3 & 349567 & 21 & 1048701 & 1 \\
\hline
\end{tabular}

Табл. 2. Ключі М для генератора BBS

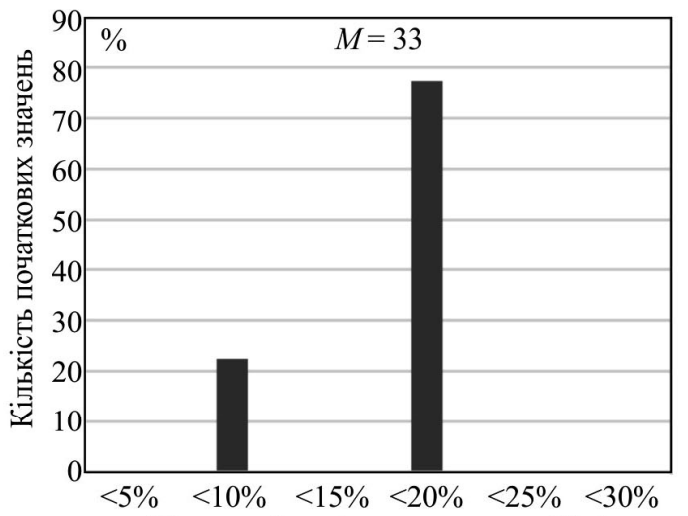

Відносний період повторення, $P\left(x_{0}\right)$

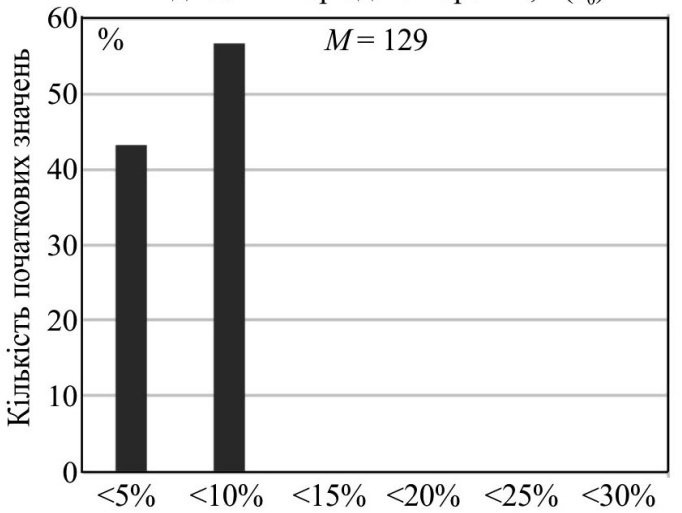

Відносний період повторення, $P\left(x_{0}\right)$

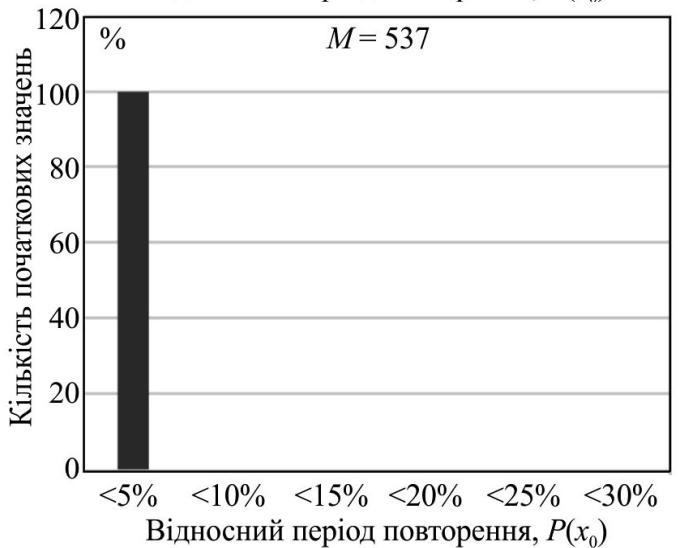



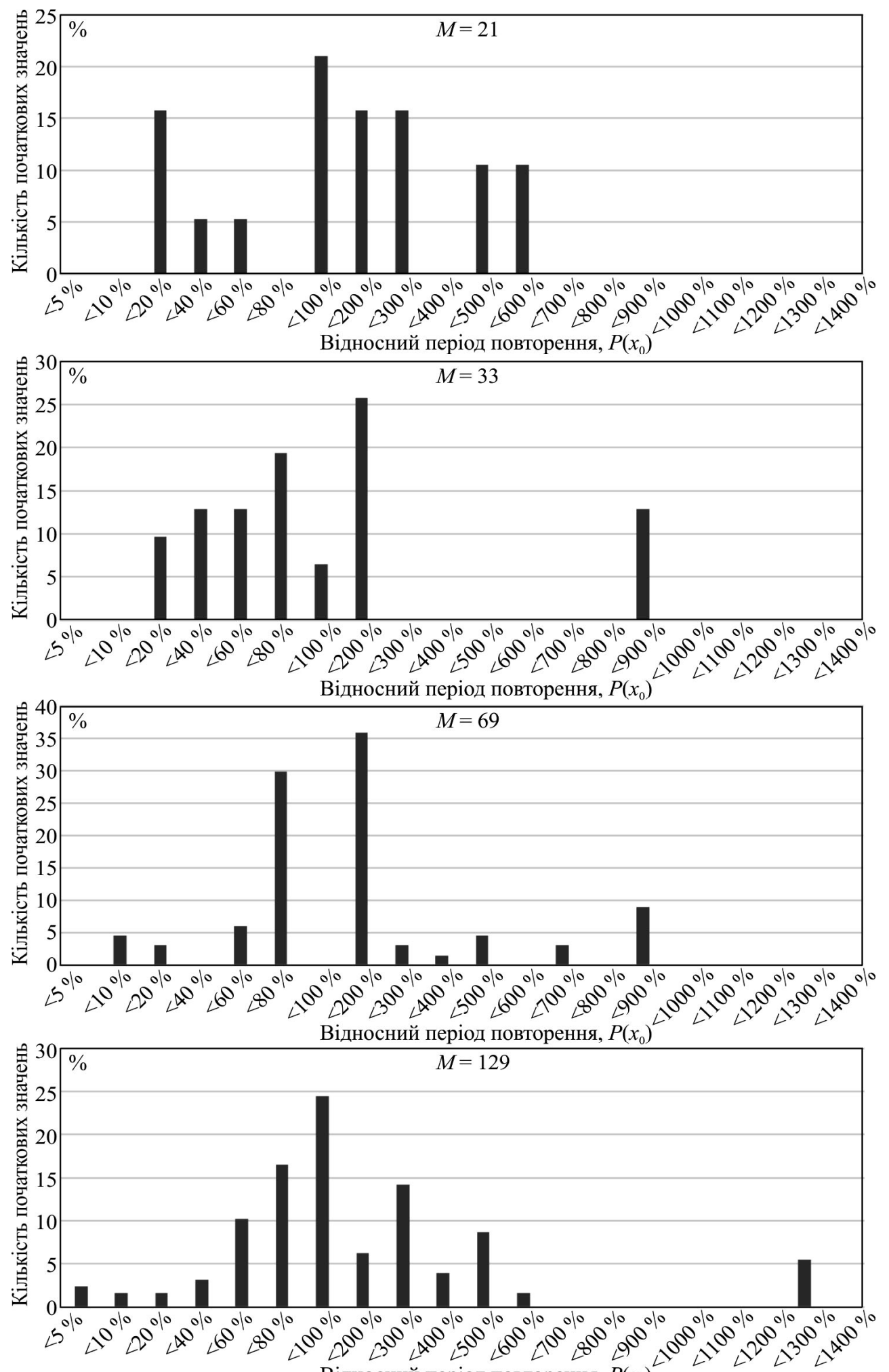

Відносний період повторення, $P\left(x_{0}\right)$

Рис. 2. Значення відносного періоду повторення від початкових значень для модифікованого алгоритму BBS

Табл. 3. Ключі М і початкові значення $x_{0}$ для генератора BBS

\begin{tabular}{|c|c|c|c|c|c|c|c|c|c|}
\hline \multirow{2}{*}{$\begin{array}{c}\text { № } \\
\text { п/п }\end{array}$} & \multirow{2}{*}{$\begin{array}{l}\text { Значення } \\
\text { ключа } M\end{array}$} & \multicolumn{6}{|c|}{ Значення періоду повторення для відповідного початкового значення $x_{0}$} \\
\cline { 3 - 10 } & & 2 & $\sqrt{M} / 2$ & $\sqrt{M}$ & $M / 2$ & 2 & $\sqrt{M} / 2$ & $\sqrt{M}$ & $M / 2$ \\
\hline 1 & 16413 & 548 & 548 & 548 & 548 & 10580 & 2582 & 4110 & 13602 \\
\hline 2 & 32817 & 913 & 1824 & 913 & 913 & 32242 & 25258 & 188872 & 72042 \\
\hline 3 & 65553 & 222 & 222 & 222 & 222 & 207660 & 27044 & 177472 & 243112 \\
\hline 4 & 131073 & 10 & 18 & 18 & 10 & 214878 & 2412622 & 268796 & 1454632 \\
\hline 5 & 262149 & 36 & 36 & 36 & 36 & 195254 & 423172 & 130082 & 4181122 \\
\hline 6 & 524289 & 20 & 20 & 20 & 20 & 594348 & 615766 & 1963562 & 4027492 \\
\hline 7 & 1048701 & 422 & 422 & 422 & 422 & 759280 & 211490 & 9536662 & 1104432 \\
\hline
\end{tabular}


Оскільки перебір усіх початкових значень $x_{0}$ для великих значень ключа $M$ вимагає великих ресурсів, то наступні дослідження проводили для окремих вибраних значень $M$, наведених у табл. 2 , і фіксованих значеннях $x_{0}$, наведених у табл. 3.3 цієї таблиці видно, що тенденція до збільшення періоду повторення псевдовипадкової послідовності чисел для модифікованого генератора BBS зберігається для ключів більшої довжини.

Дослідження та порівняльний аналіз статистичних характеристик класичного і модифікованого алгоритмів BBS генераторів. Статистичні характеристики псевдовипадкових послідовностей чисел проаналізували для вибраних ключів із найменшим значенням НСД відповідно до виразу (4) завдовжки від 29 до 31 бітів, які задовольняють умову (3) (табл. 4). Для кожного ключа підібрали два початкові значення, які розраховували за такими формулами:

$$
\begin{gathered}
x_{0}=\lfloor\sqrt{M} / 2\rfloor . \\
x_{0}=\lfloor\sqrt{M}\rfloor .
\end{gathered}
$$

Табл. 4. Ключі $M$ для генератора BBS

\begin{tabular}{|c|c|c|c|c|c|}
\hline \multirow{2}{*}{$\begin{array}{c}\text { № } \\
\text { п/п }\end{array}$} & \multicolumn{2}{|c|}{ Число Блюма } & $\begin{array}{c}\text { Довжина } \\
\text { ключа } M \text {, біт }\end{array}$ & $\begin{array}{c}\text { Значення } \\
\text { ключа } M\end{array}$ & $\begin{array}{c}\text { Значення } \\
\text { НСД }\end{array}$ \\
\hline 1 & 17519 & 18119 & 29 & 317426761 & 2 \\
\hline 2 & 21419 & 24407 & 30 & 595994533 & 2 \\
\hline 3 & 45707 & 45887 & 31 & 2097357109 & 2 \\
\hline
\end{tabular}

Аналіз статистичних характеристик подано у вигляді статистичних портретів на рис. 3-8, де на рис. 3, 5 та 7 наведено портрети класичних генераторів BBS для початкових значень, обрахованих з формул (15) зліва та (16) справа відповідно, а модифіковані версії цих генераторів - на рис. 4,6 та 8 .
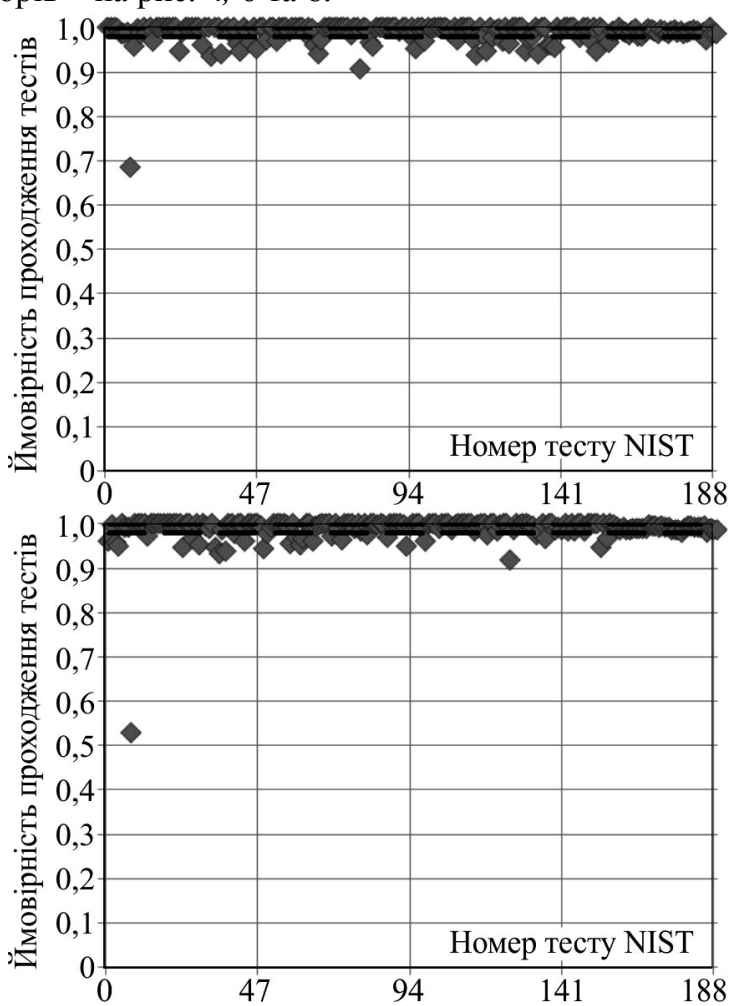

Рис. 3. Статистичні портрети класичних генераторів - варіант № 1
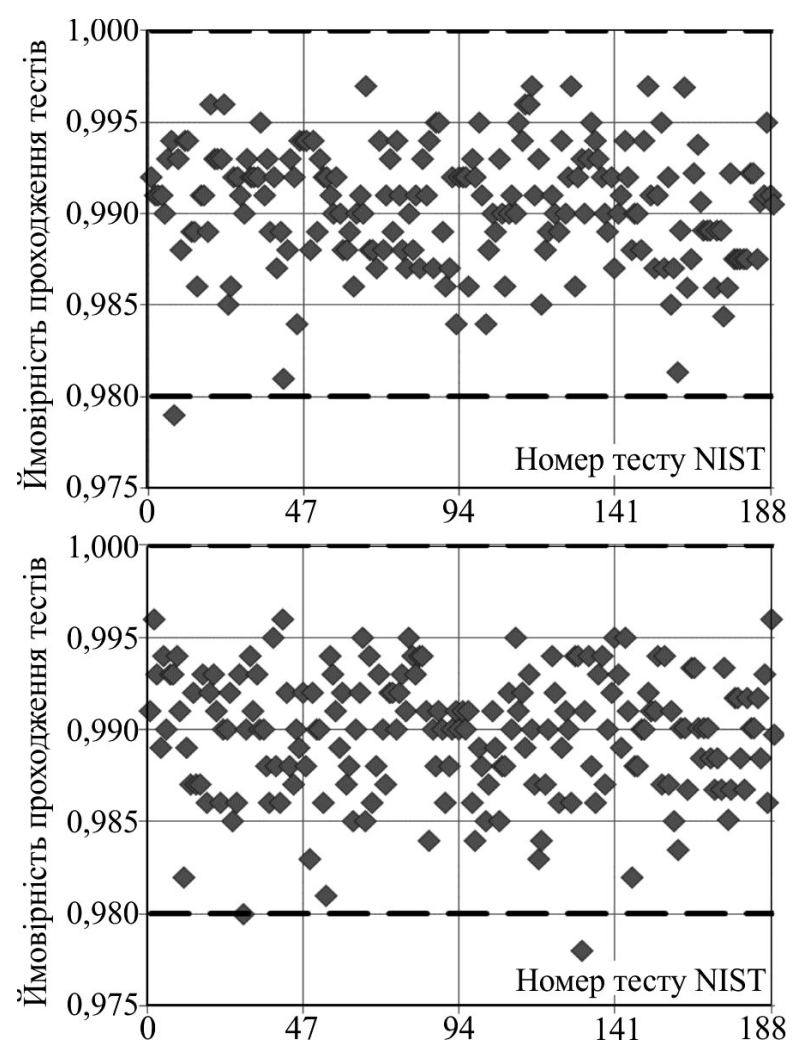

Рис. 4. Статистичні портрети модифікованих генераторів - варіант № 1

Як видно $з$ рис. 3 та 4, усі генератори псевдовипадкових послідовностей чисел не відповідають вимогам випадковості, оскільки значення проходження окремих тестів містяться поза межами довірчого інтервалу. Але запропонована модифікація генератора BBS має значно кращі статистичні характеристики.
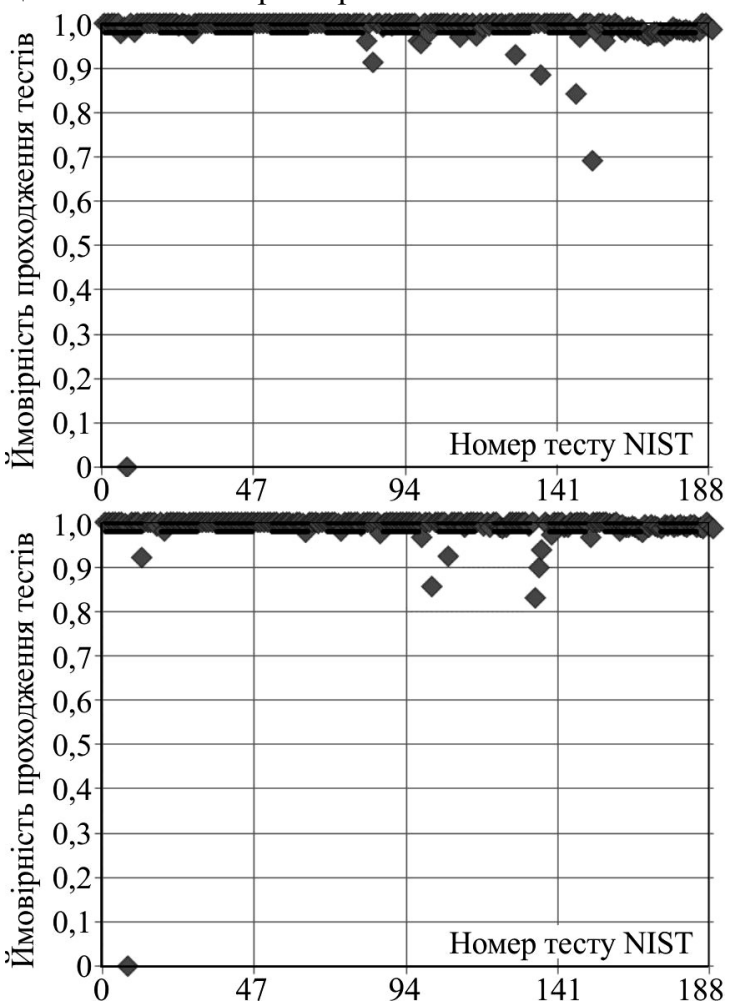

Рис. 5. Статистичні портрети класичних генераторів - варіант № 2 

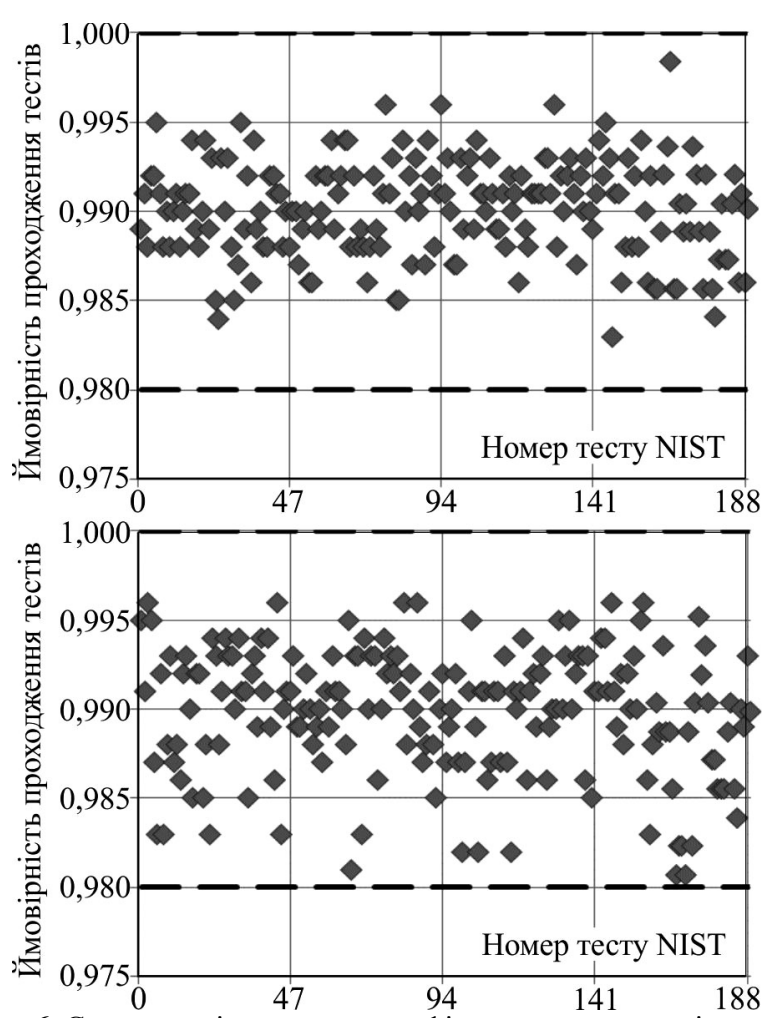

Рис. 6. Статистичні портрети модифікованих генераторів - варіант № 2

Із статистичного портрету (див. рис. 6) видно, що модифікований генератор для обох початкових значень (варіант № 2) пройшов усі тести NIST, що свідчить про його статистичну безпеку, на відміну від класичного варіанта генератора BBS.
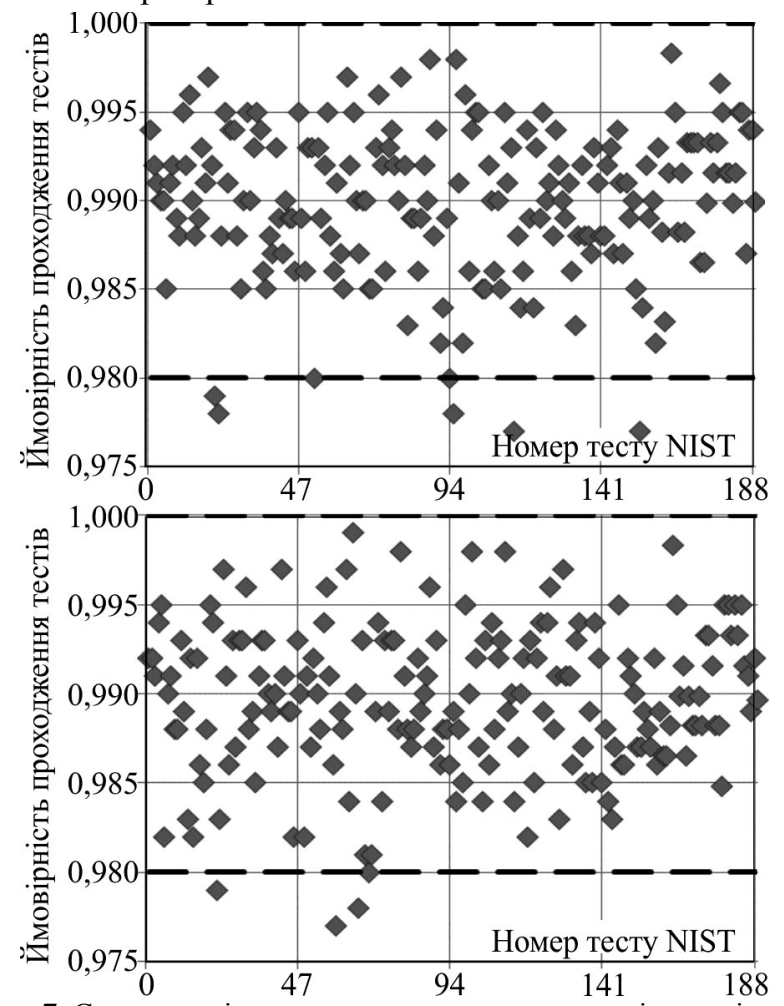

Рис. 7. Статистичні портрети класичних генераторів - варіант № 3

Статистичні портрети на рис. 4, 6 та 8 свідчать по істотне покращення статистичних характеристик модифікованого BBS генератора порівняно із класичним варіантом (див. рис. 3, 5 та 7).
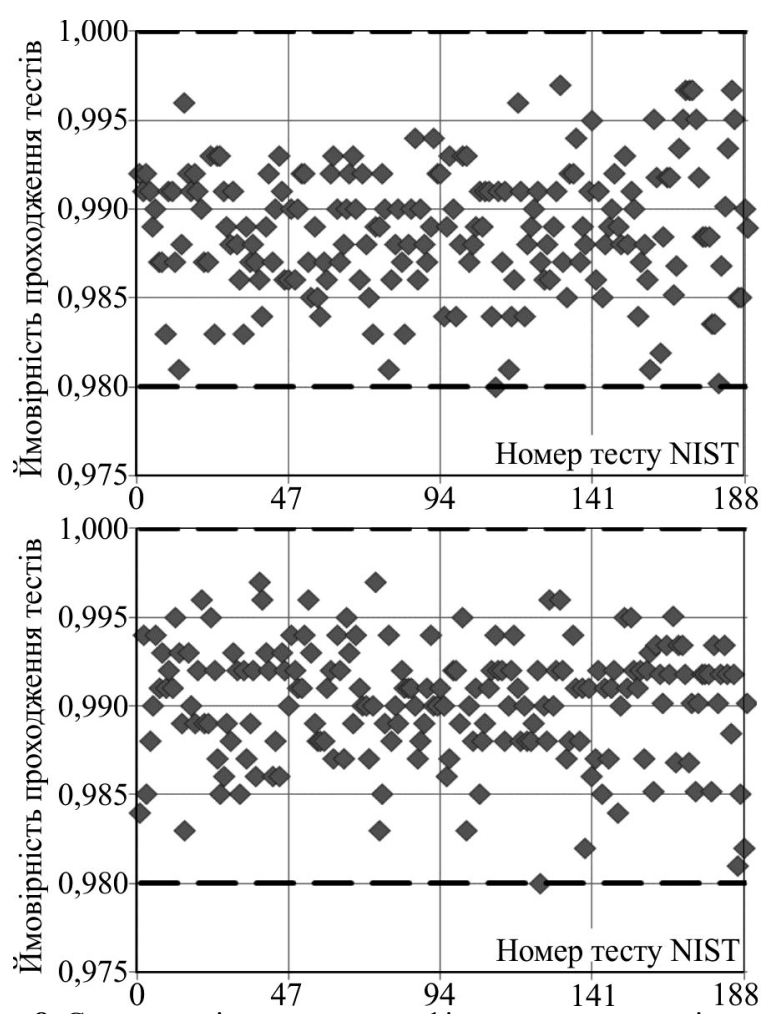

Рис. 8. Статистичні портрети модифікованих генераторів - варіант № 3

Класичний алгоритм BBS не має прийнятних статистичних портретів для ключів завдовжки 29-31 бітів. Модифікований алгоритм BBS має прийнятні статистичні портрети, починаючи 3 ключа довжиною 30 біт (див. рис. 6), тобто модифікований алгоритм BBS дає змогу отримати прийнятні статистичні портрети при використанні ключа $M$, значення якого є меншим порівняно із класичним алгоритмом, що дає змогу використовувати менше необхідних системних ресурсів для генерування псевдовипадкової послідовності, оскільки основна ресурсозатратна операція - це піднесення до квадрата.

Обговорення результатів дослідження. Значне підвищення періоду повторення для модифікованого алгоритму BBS зумовлене збільшенням кількості змінних вхідних параметрів для однієї ітерації алгоритму, які $\epsilon$ умовно незалежні між собою: хоча поточне значення послідовності отримане 3 попереднього, але операція піднесення до квадрата за модулем ключа продукує псевдовипадкові числа.

Статистичні портрети для згенерованих послідовностей демонструють кращі статистичні характеристики модифікованого алгоритму BBS, який має прийнятні статистичні портрети для ключів завдовжки 30 та 31 бітів. Порівнюючи статистичні портрети на рис. 4 та 7 , можна відзначити подібність статистичних портретів для 31-бітного ключа для класичного алгоритму та 29бітного модифікованого, тобто отриманий виграш у довжині ключа становить $6,45 \%$.

Результати отримано з використанням кращих ключів для класичного алгоритму BBS, які були вибрали на підставі формули (4).

Висновки. У роботі проаналізовано статистичні характеристики модифікованого алгоритму BBS. У ході дослідження отримано такі результати:

1. Період повторення класичного алгоритму не перевищує $20 \%$ для ключів із малим значенням, який зі збільшен- 
ням значення ключа, на вибраних початкових установках, не перевищує 5,56 \%. Період повторення модифікованого алгоритму BBS для малих значень ключа у середньому становить $200 \%$ від значення ключа, а для вибраних початкових установках за більших значень ключа $-351 \%$.

2. Отримані статистичні портрети підтверджують покращення статистичних характеристик модифікованого алгоритму BBS: згенеровані послідовності для ключів завдовжки 30-31 бітів із вибраними початковими установками мають задовільні статистичні портрети для модифікованого алгоритму, на відміну від класичного.

3. Кращі статистичні характеристики модифікованого алгоритму BBS дають змогу генерувати псевдовипадкові послідовності на базі ключів меншого розміру, тобто використовують значно менше ресурсів системи, попри додаткові операції додавання, оскільки операція піднесення до квадрата за модулем використовує значно більше ресурсів, ніж операція додавання.

Подальші дослідження в цьому напрямку можуть бути спрямовані на апаратну реалізацію модифікованого алгоритму BBS, а також на аналіз ресурсів системи, потрібних для його реалізації, порівняно із класичним алгоритмом.

\section{References}

1. Aïssa, B., Khaled, M., \& Lakhdar, G. (2014). Implementation of Blum Blum Shub generator for message encryption: proceedings of the International Conference on Control, Engineering and Information Technology (CEIT14). Tunisia, 6, pp. 118-123.

2. Blum, L., Blum, M., \& Shub, M. (1983). Comparison of two pseudo-random number generators: proceedings of the Workshop on the Theory and Application of Cryptographic Techniques CRYPTO82. New York, pp. 61-78.

3. Blum, L., Blum, M., \& Shub, M. (1986). A simple unpredictable pseudorandom number generator: SIAM. Journal on Computing, 15(2), 364-383.
4. Divyanjali, Ankur, Pareek, V. (2014). An overview of cryptographically secure pseudorandom number generators and BBS: IJCA proceedings of the International Conference on Advances in Computer Engineering and Applications ICACEA. March 2014, 2(3), 19-28.

5. Gawande, K., \& Mundle, M. (2003). Various implementations of Blum Blum Shub pseudo-random sequence generator, Conference Proceedings. Retrieved from: https://pdfs.semanticscholar.org/5ddc/47b658a204ae76d00aec929b1a5b7fbbfaa6.pdf

6. Gurpreet, S., \& Gurjot, G. (2017). DNA and Blum Blum Shub Random Number Generator Based Security Key Generation Algorithm. International Journal of Security and its Applications, 11, 1-10.

7. Junod, P. (1999). Cryptographic secure pseudo-random bits generation: The Blum-Blum-Shub generator. Retrieved from: http://crypto.junod.info/bbs.pdf

8. Kapur, V., \& Teja, S. (2015). Two level image encryption using pseudo random number generators. International Journal of Computer Applications, 115(12), 1-4.

9. Lopez, P., \& Millan, E. (2010). Cryptographically secure pseudorandom bit generator for RFID tags: proceedings of the International Conference for Internet Technology and Secured Trans. London, 8-11 Nov 2010, pp. 1-6.

10. Malohlovets, A. C., \& Maksymovych, V. M. (2017). Metody pokrashchennia statystychnykh kharakterystyk kryptostiikykh heneratoriv BBS psevdovypadkovykh chysel i bitovykh poslidovnostei. Zakhyst informatsii i bezpeka informatsiinykh system: materialy VI Mizhnarodnii konferentsii (m. Lviv, 1 chervnia 2017), Lviv, 73-74. [In Ukrainian].

11. NIST SP 800-22. (2019). A Statistical Test Suite for Random and Pseudorandom Number Generators for Cryptographic Applications. Retrieved from: http://csrc.nist.gov/publications/nistpubs/800-22-rev1a/SP800-22rev1a.pdf.

12. Shrestha, B. (2016). Multiprime Blum-Blum-Shub Pseudorandom Number Generator, $\mathrm{PhD}$ thesis. Retrieved from: https://apps.dtic.mil/dtic/tr/fulltext/u2/1030047.pdf

13. Sidorenko, A., \& Schoenmakers, B. (2005). Concrete security of the Blum-Blum-Shub pseudorandom generator: Cryptography and Coding, Lecture Notes on Computer Science, Springer. Nov 2005, 37(96), 355-375.

A. S. Malohlovets

Lviv Polytechnic National University, Lviv, Ukraine

\section{RESEARCH OF STATISTICAL CHARACTERISTICS FOR IMPROVED BBS ALGORITHM WITH DEPENDENCY ON THE CURRENT AND PREVIOUS VALUES OF THE SEQUENCE}

The Blum-Blum-Shub generator, BBS, is based on one-sided factorization function and is cryptographically secure pseudorandom number generator. It has been widely used in information security systems. The paper investigates the characteristics of the modified BBS algorithm with dependency on the current and previous values of the sequence, in particular, the repetition period and the statistical characteristics of the original sequence, depending on the parameters of the generator. The studies were performed using NIST Statistical Test Suite, results of which were compared to the results of the classical BBS algorithm. It is found that the repetition period of the classical BBS algorithm for small key values, from 5 to 10 bits, is not more than $20 \%$ of its value. This trend persists on larger keys, from 15 to 21 bits, where the repetition period for selected initial installations does not exceed $5.56 \%$. The repetition period of the modified BBS algorithm for keys from 5 to 10 bits averages $200 \%$ of the key value. This behavior is retained on the selected initial installations for keys from 15 to 21 bits, which have an average repetition period of $351 \%$. The study of statistical characteristics by the NIST statistical test suite was performed on generated sequences with 109 bits length for keys with length from 29 to 31 bits. The statistical portraits for the classical algorithm have been found to be unsatisfactory, but the statistical portraits for the 31-bit key have up to 5 unsatisfactory results out of 188 tests. Statistical portraits for the modified BBS algorithm are satisfactory for keys from 30 to 31 bits, but statistical portraits are not satisfactory for 29-bit keys, because they have 1 poor result. Therefore, the modified BBS algorithm has better repetition period values and statistical portraits compared to the classical algorithm, which allows the use of keys with shorter length for sequences generation, which requires less system resources, since the module-squaring operation is more complex than the addition operation. Further studies will focus on the hardware implementation of the modified BBS algorithm and the comparison of system resources used with the implementation of the classical BBS algorithm.

Keywords: pseudorandom sequence; pseudorandom sequence generators; one-way functions; Blum-Blum-Shub generators. 